\title{
Teaching NeuroImage: Dynamic MRI in the Evaluation of Cervical Myelopathy
}

Miguel Quintas-Neves, MD, and Ângelo Carneiro, MD, MSc

Neurology ${ }^{\circledR}$ 2021;97:e1359-e1360. doi:10.1212/WNL.0000000000012181

Correspondence

Dr. Quintas-Neves

mlqneves@gmail.com

Figure 1 Dynamic MRI of the Cervical Spine, Sagittal View

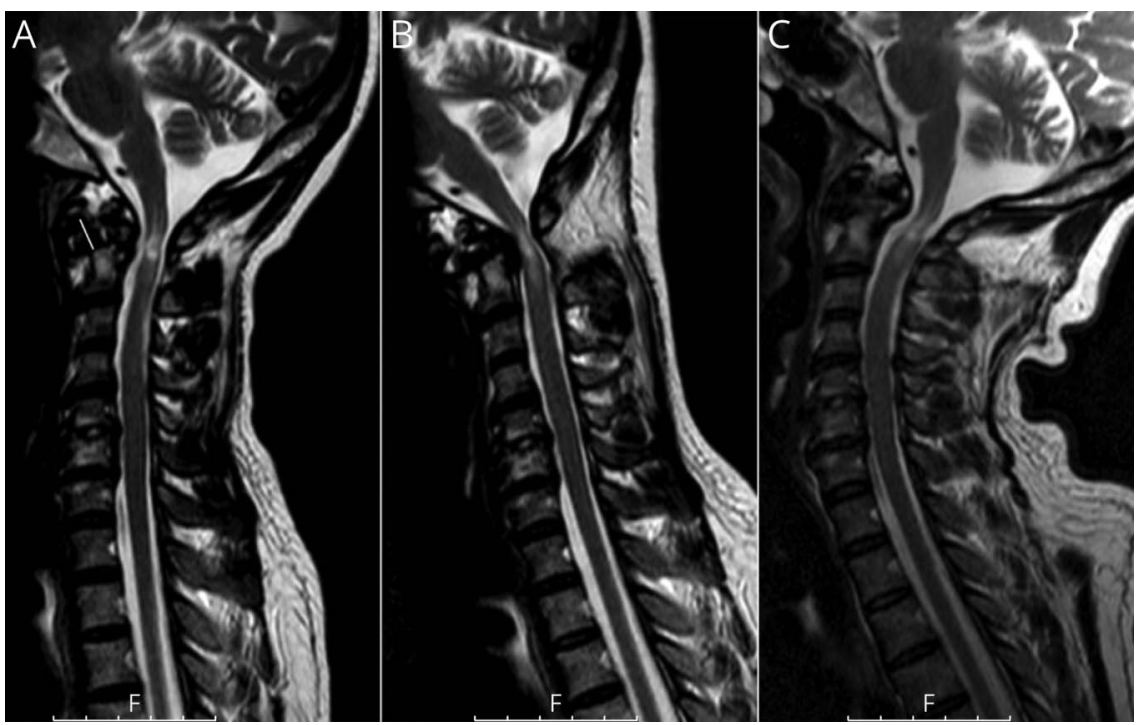

Sagittal T2-weighted imaging at rest (A), flexion (B), and extension (C). Spinal cord hyperintensity at the C1 level is depicted, suggesting gliosis/edema. There is also increased atlanto-dental interval (white line in A) and periarticular fibrosis. During flexion (B), severe canal stenosis is unveiled, favoring atlanto-axial instability.

A 44-year-old woman, with a childhood history of motor vehicle accident, was referred to neurosurgery due to progressive tetraparesis, inability to walk, generalized hyperreflexia, and bilateral extensor plantar reflexes (American Spinal Injury Association Impairment Scale D/ Japanese Orthopaedic Association score 7), without bowel/bladder dysfunction. Dynamic MRI (Figures 1 and 2) showed spinal cord edema/gliosis at the $\mathrm{C} 1$ level and atlanto-axial subluxation. During flexion, severe spinal canal stenosis was observed, confirming atlanto-axial instability. Posterior arthrodesis was performed and resulted in resolution of instability with no neurologic deterioration after 3 months. Dynamic MRI in the supine position can be an accurate technique to unveil occult cervical canal stenosis. ${ }^{1,2}$ Although most cases are revealed or aggravated during extension, flexion should also be tested. ${ }^{2}$

\section{Study Funding}

The authors report no targeted funding.

\section{Disclosure}

The authors report no disclosures relevant to the manuscript. Go to Neurology.org/N for full disclosures. 
Figure 2 MRI of the Cervical Spine, Axial View

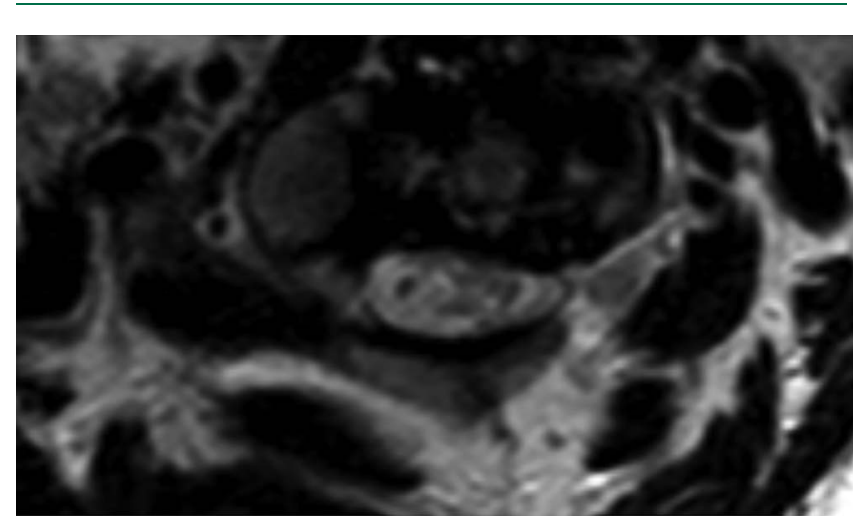

Axial T2-weighted imaging at rest at the level of C1 confirms the bilateral spinal cord hyperintense lesion, in keeping with gliosis/edema.

\section{Appendix Authors}

\begin{tabular}{lll}
\hline Name & Location & Contribution \\
\hline $\begin{array}{l}\text { Miguel } \\
\text { Quintas- } \\
\text { Neves, MD }\end{array}$ & $\begin{array}{l}\text { Department of } \\
\text { Neuroradiology, Hospital } \\
\text { de Braga, Portugal }\end{array}$ & $\begin{array}{l}\text { Acquisition of data, clinical and } \\
\text { imaging data review, literature } \\
\text { review, final manuscript } \\
\text { writing }\end{array}$ \\
\hline $\begin{array}{l}\text { Ângelo } \\
\text { Carneiro, } \\
\text { MD, MSc }\end{array}$ & $\begin{array}{l}\text { Neuroradiology, Hospital } \\
\text { de Braga, Portugal }\end{array}$ & $\begin{array}{l}\text { Clinical and imaging data review, } \\
\text { literature review, final } \\
\text { manuscript writing }\end{array}$ \\
\hline
\end{tabular}

\section{References}

1. Zeitoun D, El Haij F, Sariali E, Catonné Y, Pascal-Moussellard H. Evaluation of spina cord compression and hyperintense intramedullary lesions on T2-weighted sequences in patients with cervical spondylotic myelopathy using flexion-extension MRI protocol. Spine J. 2015;15(4):668-674.

2. Nanfang X, Shaobo W, Huishu Y, Xiaoguang L, Zhongjun L. Does dynamic supine magnetic resonance imaging improve the diagnostic accuracy of cervical spondylotic myelopathy? A review of the current evidence. World Neurosurg. 2017;100: 474-479 


\section{Neurology}

\section{Teaching NeuroImage: Dynamic MRI in the Evaluation of Cervical Myelopathy}

Miguel Quintas-Neves and Ângelo Carneiro

Neurology 2021;97;e1359-e1360 Published Online before print May 24, 2021

DOI 10.1212/WNL.0000000000012181

This information is current as of May 24, 2021

Updated Information \&

Services

References

Subspecialty Collections

Permissions \& Licensing

Reprints including high resolution figures, can be found at: http://n.neurology.org/content/97/13/e1359.full

This article cites 2 articles, 0 of which you can access for free at: http://n.neurology.org/content/97/13/e1359.full\#ref-list-1

This article, along with others on similar topics, appears in the following collection(s):

MRI

http://n.neurology.org/cgi/collection/mri

Spinal cord trauma

http://n.neurology.org/cgi/collection/spinal_cord_trauma

Information about reproducing this article in parts (figures,tables) or in its entirety can be found online at:

http://www.neurology.org/about/about_the_journal\#permissions

Information about ordering reprints can be found online:

http://n.neurology.org/subscribers/advertise

Neurology ${ }^{\circledR}$ is the official journal of the American Academy of Neurology. Published continuously since 1951, it is now a weekly with 48 issues per year. Copyright @ 2021 American Academy of Neurology. All rights reserved. Print ISSN: 0028-3878. Online ISSN: 1526-632X.

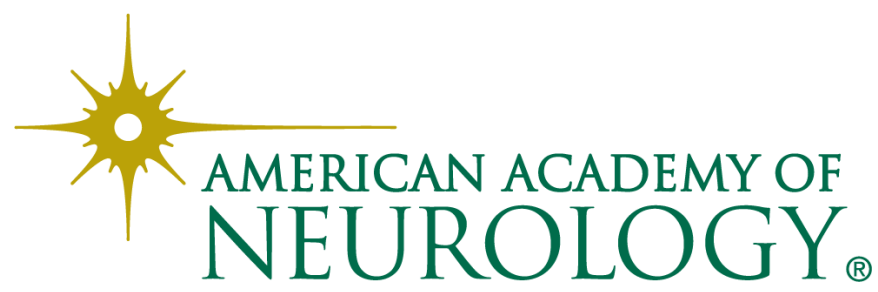

